\title{
Neuropathy Associated with Hepatitis in Patients Maintained on Haemodialysis
}

\author{
A. M. DAVISON, I. R. WILLIAMS, C. MAWDSLEY, J. S. ROBSON
}

British Medical fournal, 1972, 1, 409-411

\section{Summary}

During a study of peripheral nerve function in chronic renal failure, 11 patients who were being treated by chronic intermittent haemodialysis developed serum hepatitis. Before the infection there was a trend towards improvement in nerve conduction velocities. A pronounced deterioration in the conduction velocities in motor fibres of peripheral nerves occurred in association with hepatitis. In the months after recovery from the infection there was again a trend towards improvement in conduction velocities. We suggest that this reflects the occurrence of a peripheral neuropathy which is at least in part demyelinating. The neuropathy is related to the serum hepatitis, but its pathogenesis is indeterminate.

\section{Introduction}

Peripheral neuropathy is one of the complications of chronic renal failure (Scribner, 1967). We have carried out a study of peripheral nerve conduction velocities in patients suffering from chronic renal failure. During the study a number of patients being treated by chronic intermittent haemodialysis developed serum hepatitis. This report is concerned with the effect of this illness on peripheral nerve conduction velocity.

\section{Patients}

All patients undergoing haemodialysis had routine liver function tests performed regularly, and blood was routinely examined for the presence of hepatitis-associated antigen. Those who

University of Edinburgh and Royal Infirmary, Edinburgh EH3 9YW A. M. DAVISON, M.B., CH.B., M.R.C.P., Registrar, Medical Renal Unit I. R. WILLIAMS, M.B., CH.B., M.R.C.P., Lecturer, Department of Medical

Neurology
C. MAWDSLY, M.B., CH.B., F.R.C.P.ED., Senior Lecturer, Department of Medical Neurology

J. S. ROBSON, M.D., F.R.C.P.ED., Reader, Department of Medicine developed changes in these indices were regarded as having hepatitis. Eleven patients who developed serum hepatitis were included in the study of nerve conduction velocities. They suffered from chronic renal failure and were maintained on regular haemodialysis. Eight of them had been dialysed for more than one year. No patient had any other disease which might cause peripheral neuropathy. They received a diet containing $50 \mathrm{~g}$ of protein and $0.5 \mathrm{~g}$ of sodium each day, and potassium intake was restricted. A greater reduction of protein intake was implemented in two patients who were comatose for one week. Daily vitamin supplements were taken by all patients.

\section{Methods}

Nerve conduction velocities were estimated in the motor fibres of the median, ulnar, and anterior tibial nerves. The latency of the H-reflex was measured. All measurements were made in the same environment with skin electrodes and a DISA two-channel electromyograph. Skin temperature was maintained at or above $30^{\circ} \mathrm{C}$. Nerve conduction velocities were measured immediately before a period of dialysis. After each study the serum concentrations of urea and creatinine were measured.

\section{Results}

Hepatic Damage.-The results of patients' liver function tests when they were maximally deranged and the corresponding values six months later are shown in Table $I$. The duration of each patient's stay in hospital and the occurrence of neurological abnormalities are listed. Two patients became comatose, and one had a grand mal convulsion.

Uraemia.-There was no significant difference in the control of uraemia before, during, and after hepatitis.

Nerve Conduction Velocities. - In most patients nerve conduction velocities were measured on four occasions-twice before the onset of hepatitis and twice after recovery. The time interval between successive studies varied. The intervals between studies and their relation to the onset of hepatitis are shown in Fig. 1. These four consecutive measurements delineate three periods: a period of treated chronic renal failure before the

TABLE I-Liver Function and Severity of Illness

\begin{tabular}{|c|c|c|c|c|c|c|c|c|c|c|}
\hline \multirow{2}{*}{$\begin{array}{l}\text { Case } \\
\text { No. }\end{array}$} & \multicolumn{4}{|c|}{$\begin{array}{c}\text { During Hepatitis } \\
\text { Routine Liver Function Tests } \\
\text { Maximal Levels }\end{array}$} & \multirow{2}{*}{$\begin{array}{c}\text { Length } \\
\text { of Time } \\
\text { in Hospital } \\
\text { (Weeks) }\end{array}$} & \multirow{2}{*}{$\begin{array}{c}\text { Neurological } \\
\text { Symptoms/Signs }\end{array}$} & \multicolumn{4}{|c|}{$\begin{array}{l}\text { Six Months after Hepatitis } \\
\text { Routine Liver Function Tests }\end{array}$} \\
\hline & $\underset{(\mathbf{m g} / 100 \mathbf{m l})}{\text { Bilirubin }}$ & $\underset{\text { (units/ml) }}{\text { SGPT* }}$ & $\begin{array}{l}\text { A.P. } \dagger \\
\text { (K.A. units/ } \\
100 \mathrm{ml})\end{array}$ & H.A.A. $\ddagger$ & & & $\underset{(\mathbf{m g} / \mathbf{1 0 0} \mathbf{~ m l})}{\text { Bilirubin }}$ & $\underset{\text { (units/ml) }}{\text { SGPT* }}$ & $\begin{array}{l}\text { A.P.† } \\
(\text { K.A. units/ } \\
100 \mathrm{ml})\end{array}$ & H.A.A. $\neq$ \\
\hline $\begin{array}{l}1 \\
2 \\
3 \\
4 \\
5 \\
6 \\
7 \\
8 \\
8 \\
9\end{array}$ & $\begin{array}{c}4 \cdot 1 \\
4 \cdot 2 \\
7.5 \\
10 \\
6 \cdot 1 \\
3 \cdot 7 \\
0.8 \\
5.6 \\
11 \cdot 0\end{array}$ & $\begin{array}{r}83 \\
>600 \\
260 \\
>900 \\
680 \\
233 \\
620 \\
450 \\
>800\end{array}$ & $\begin{array}{r}32 \\
27 \\
130 \\
60 \\
45 \\
75 \\
24 \\
28 \\
19\end{array}$ & $\begin{array}{l}+ \\
+ \\
+ \\
+ \\
+ \\
+ \\
+ \\
+\end{array}$ & $\begin{array}{l}5 \\
0 \\
1 \\
1 \\
0 \\
0 \\
0 \\
4 \\
7\end{array}$ & $\begin{array}{l}\text { None } \\
\text { None } \\
\text { Convulsion } \\
\text { None } \\
\text { None } \\
\text { None } \\
\text { None } \\
\text { None } \\
\text { Coma: hemiplegia } \\
7 \text { days }\end{array}$ & $\begin{array}{l}1.8 \\
0.4 \\
1.0 \\
0.4 \\
0.3 \\
0.6 \\
0.3 \\
0.7 \\
0.5\end{array}$ & $\begin{array}{r}15 \\
22 \\
35 \\
22 \\
17 \\
57 \\
13 \\
7\end{array}$ & $\begin{array}{l}13 \\
36 \\
21 \\
11 \\
60 \\
19 \\
22 \\
20\end{array}$ & $\begin{array}{l} \pm \\
\pm \\
\pm \\
\pm \\
\pm \\
=\end{array}$ \\
\hline 10 & $44 \cdot 0$ & 280 & 30 & + & 12 & $\begin{array}{l}\text { Coma: disorientation, } \\
\text { confusion, } \\
\text { hallucinations } \\
\text { None }\end{array}$ & $1 \cdot 1$ & 12 & 18 & - \\
\hline
\end{tabular}




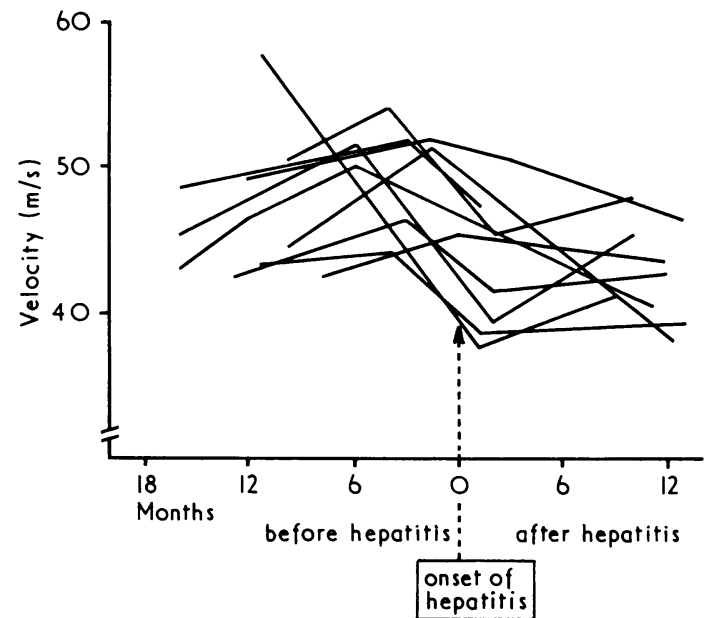

FIG. 1-Conduction velocity in motor fibres of the median nerve in the forearm. Results of consecutive studies showing the time interval between studies and their relation to the onset of hepatitis.

development of hepatitis, a period during which the patients suffered from hepatitis, and a period after recovery from the infection. The results of these studies are shown in Table II. The paired $t$ test was used for statistical analysis.

Median Nerve.-The means of the latencies of the muscle action potentials after stimulation at the wrist and of conduction velocities in the motor fibres of the proximal segments of the median nerve are shown in Table II. Before the development of hepatitis conduction velocities increased and the distal latencies

TABLE II-Nerve Conduction Velocity: Mean Values ( \pm S.D.) for Each of Four Consecutive Studies

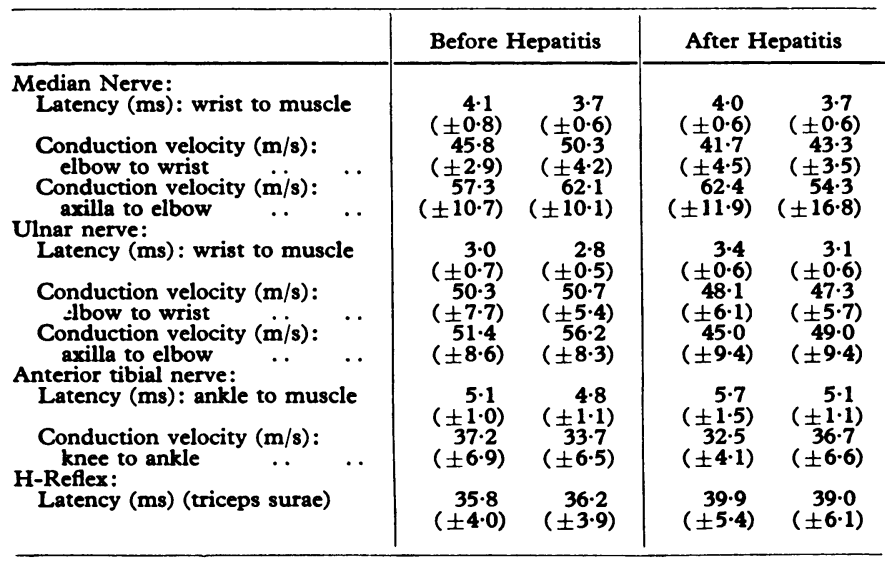

decreased between the two recordings. The change is highly significant in the segment between the elbow and the wrist $(\mathrm{P}<0.001)$. A comparison of results before and after hepatitis shows a highly significant fall in conduction velocity in the forearm segment $(P<0.001)$. The associated increase in latency at the wrist is not statistically significant. There was no alteration in the velocities estimated in the segment of nerve between axilla and elbow.

Ulnar Nerve.-Before hepatitis there was an increase in conduction velocity in the forearm segment of the ulnar nerve and a decrease in the response latency after stimulation at the wrist. The changes fail to reach significance. During the period in which the patients suffered from hepatitis there was a fall in conduction velocity in the upper arm $(P<0.02)$ and forearm segments and the distal latency increased $(P<0.001)$. After recovery from hepatitis there was a trend towards improvement in the upper arm nerve conduction velocity and in the distal latency.

Anterior Tibial Nerve.-The latency of the muscle response after stimulation of the nerve at the ankle decreased in the period before hepatitis and increased during the time in which the patients had hepatitis $(P<0.05)$. None of the changes in conduction velocity reached the $5 \%$ level of significance. After recovery from hepatitis there was a trend towards improvement in both measurements.

H-Reflex (Triceps Surae).-The latency of the H-reflex showed no change before hepatitis but increased during the illness $(P<0 \cdot 05)$. The subsequent fall does not reach statistical significance.

Summary of Nerve Conduction Studies.-Nerve conduction velocities deteriorated during the period in which patients suffered from hepatitis. The deterioration occurred in all segments of each nerve studied other than the proximal part of the median nerve. Before the development of hepatitis all measurements other than the latency of the $\mathrm{H}$-reflex and conduction velocity in the anterior tibial nerve had improved. After recovery from hepatitis there was an improvement in all measurements other than conduction velocity in the most proximal part of the median nerve and in the distal segment of the ulnar nerve.

Serum Urea and Creatinine.-In patients receiving chronic intermittent haemodialysis there was a correlation between some of the nerve conduction velocities and the serum concentrations of urea or creatinine. After hepatitis there was no longer any such correlation (Table III).

TABLE III-Correlation Coefficients: Nerve Conduction Studies and Serum Urea and Creatinine Concentrations before and after Hepatitis

\begin{tabular}{|c|c|c|c|c|}
\hline & \multicolumn{2}{|c|}{ Urea } & \multicolumn{2}{|c|}{ Creatinine } \\
\hline & $\begin{array}{c}\text { Before } \\
\text { Hepatitis }\end{array}$ & $\begin{array}{c}\text { After } \\
\text { Hepatitis }\end{array}$ & $\begin{array}{c}\text { Before } \\
\text { Hepatitis }\end{array}$ & $\begin{array}{c}\text { After } \\
\text { Hepatitis }\end{array}$ \\
\hline $\begin{array}{l}\text { Median nerve: } \\
\text { Wrist latency } . . \\
\text { Velocity: axilla to cubital fossa } \\
\text { Velocity: cubital fossa to wrist } \\
\text { Ulnar nerve: }\end{array}$ & $\begin{array}{l}0.49 * \\
-0.07 \\
-0.25\end{array}$ & $\begin{array}{r}0.07 \\
0.21 \\
-0.02\end{array}$ & $\begin{aligned} & 0.64 \ddagger \\
&-0.30-0.438 \\
&-0.48\end{aligned}$ & $\begin{array}{r}-0.02 \\
0.10 \\
0.09\end{array}$ \\
\hline $\begin{array}{l}\text { Ulnar nerve: } \\
\text { Wrist latency } \\
\text { Velocity: axilla to elbow } \\
\text { Velocity: elbow to wrist }\end{array}$ & $\begin{array}{l}0.10 \\
-0.35 \\
-0.29\end{array}$ & $\begin{array}{r}-0.17 \\
0.08 \\
0.17\end{array}$ & $\begin{array}{l}0.31 \\
-0.32 \\
-0.428\end{array}$ & $\begin{array}{l}0.29 \\
0.03 \\
0.05\end{array}$ \\
\hline $\begin{array}{l}\text { Ankle latency } \\
\text { Velocity: neck of fibula to ankle } \\
\text { H-Reflex: }\end{array}$ & $\begin{array}{r}0.07 \\
-0.18\end{array}$ & $\begin{array}{l}0.03 \\
0.19\end{array}$ & $\begin{array}{c}0.34 \\
-0.41 \dagger\end{array}$ & $\begin{array}{l}0.05 \\
0.07\end{array}$ \\
\hline Latency (triceps surae) & 0.33 & -0.03 & $0.44+$ & 0.31 \\
\hline
\end{tabular}

Wrist latency $=$ time from stimulation at wrist to action potential in abductor pollicis

brevis for median nerve and abductor digiti minimi for ulnar nerve.
Ankle latency $=$ time from stimulation at ankle to action potential in extensor digi-

torum brevis. $\mathbf{P}<0.01$. $\mathbf{P}<05$. $\$ \mathbf{P}<0.001$. \& $\mathbf{P}<0.02$.

\section{Discussion}

We and others have found a deterioration in nerve conduction velocity during the first year of intermittent haemodialysis (Tenckhoff et al., 1965; Pendras and Erickson, 1966; Davison et al., 1972) followed by an improvement in the second and third years (Tenckhoff et al., 1965; Dinapoli et al., 1966; Davison et al., 1972). Eight of our 11 patients had received dialysis twice weekly for more than one year, and would be expected to show an improvement in nerve conduction velocity. Such an improvement was observed in the median nerve in the forearm and most other nerves showed a similar trend. The improvement might be due to better nutrition or to correction of the biochemical disturbance associated with renal failure. The latter explanation seems more likely in view of the correlation between the severity of the renal failure and the impairment of nerve conduction velocities (Blagg et al., 1968).

Conduction velocity in peripheral nerves might be impaired during hepatitis by a coincidental deterioration of renal failure, or by malnutrition, or because of the administration of neurotoxic drugs. If neural conduction is disrupted as a direct result of serum hepatitis it could be due either to the effect of the infecting virus or to metabolic changes secondary to hepatic parenchymal damage.

The control of renal failure, as reflected in serum concentrations of urea and creatinine, was unchanged during the period in which patients were suffering from hepatitis. It seems un- 
likely that inadequate control of renal failure was responsible for the deterioration in nerve conduction.

Anorexia at the onset of hepatitis was a feature in all patients. An adequate caloric intake was maintained, however, and vitamin supplements were continued. Half the patients had no overt protein imbalance and in the others protein loss was of a minor degree. It is therefore unlikely that protein loss or malnutrition was responsible for changes in nerve conduction.

Drug absorption and metabolism are impaired in both renal and hepatic failure. No patient received any preparation known to be neurotoxic when given to people with normal renal and hepatic function.

Previous reports of hepatitis in dialysis units have not mentioned impaired peripheral nerve function (Jones et al., 1967; Eastwood et al., 1968; London et al., 1969), but our results suggest that the two are closely linked.

Klippel and Lhermitte (1908) noted that "catarrhal infective jaundice can be complicated by a more or less generalized polyneuritis." They thought that the polyneuritis was due to the infective agent responsible for the jaundice and was not dependent on hepatic insufficiency. Lelong and Bernard (1935) reported the case of a 14-year-old girl who developed hepatitis and a predominantly motor neuropathy which improved after two months. Peripheral neuropathy has also been described in the accounts of hepatitis occurring during the second world war (Brain, 1942-3; Lescher, 1944; Byrne and Taylor, 1945; Lovell, 1945). More recent clinical and pathological observations show that a demyelinating peripheral neuropathy occurs in chronic hepatic disease (Dayan and Williams, 1967; Ortiz Vázquez et al., 1967).

Conduction in peripheral nerves can be impaired both by viral infections and by hepatic parenchymal insufficiency. The virus can exert its effect either by damaging the cell body directly, as in poliomyelitis (polioclastic), or by exciting an abnormal immune response detrimental to neural tissue. The neurological lesion might be polioclastic. The relatively minor impairment of conduction velocity would be consistent with such a pathological process.

It is possible that an immunological response to a viral infection could give rise to segmental demyelination of the peripheral nerves. The reduction in nerve conduction velocities in our study was not as pronounced as is usually found associated with widespread segmental demyelination (Gilliatt, 1966). However, the improvement after recovery from hepatitis suggests that demyelination, with subsequent remyelination, may be partly responsible for the neural changes.

Hepatic parenchymal insufficiency could damage peripheral nerves by producing unfavourable metabolic disturbances. Dayan and Williams (1967) suggested that the predominantly demyelinating peripheral neuropathy associated with chronic hepatic failure might be related to disordered insulin metabolism. Profound hypoglycaemia, though known to occur in acute hepatic necrosis, was not observed in our patients. Alterations of insulin metabolism or other metabolic pathways remain possible factors in the aetiology of the impaired neural conduction.

The interpretation of the changes in nerve conduction velocity is complicated by the pre-existing impairment of conduction associated with chronic renal failure. Our observations show a deterioration in neural conduction in patients suffering from serum hepatitis but the pathogenesis of this change is not clear.

\section{References}

Blagg, C. R., Kemble, F., and Taverner, D. (1968). Nephron, 5, 290. Brain, W. R. (1942-3). Proceedings of the Royal Society of Medicine, 36, 319. Byrne, E A J and Taylor, G F (1945). British Medical fournal, 1, 477. Davison, A. M., Williams, I. R., Mawdsley, C., Hawkes, C., Martin, A., and Robson, J. S. (1972). In preparation.

and Robson, J. S. (1972). In preparation.

Dinapoli, R. P., Johnson, W. J., and Lambert, E. H. (1966). Mayo Clinic Proceedings, 41, 809.

Eastwood, J. B., Curtis, J. R., Wing, A. J., and de Wardener, H. E. (1968). Annals of Internal Medicine, 69, 59.

Gilliatt, R. W. (1966). Proceedings of the Royal Society of Medicine, 59, 989.

Jones, P. O., Goldsmith, H. J., Wright, F. K., Roberts, C., and Watson, D. C. (1967). Lancet, 1, 835 .

Klippel, M., and Lhermitte, J. (1908). Semaine Médicale, 28, 13

Lelong, M., and Bernard, J. (1935). Bulletins et Mémoires de la Société Médicale des Hôpitaux de Paris, 59, 1749.

Lescher, F. G. (1944). British Medical fournal, 1, 554.

London, W. T., Di Figlia, M., Sutwick, A. I., and Blumberg, B. S. (1969). New England fournal of Medicine, 281, 571.

Lovell, C. (1945). British Medical fournal, $1,569$.

Ortiz Vázquez, J., Olmo, A., Muro, J., Villamor, J., and Barreiro, P. (1967). Revista Clinica Española, 104, 60.

Pendras, J. P., and Erickson, R. V. (1966). Annals of Internal Medicine, 64, 293.

Scribner, B. H. (1967). In Renal Disease, 2nd edn., ed. D. A. K. Black, p. 460. Oxford, Blackwell

Tenckhoff, H. A., Boen, F. S. T., Jebsen, R. H., and Spiegler, J. M. (1965) fournal of the American Medical Association, 192, 1121
Royal Infirmary, Edinburgh EH3 9YW

D. B. SCOTT, M.D., F.F.A. R.C.S., Consultant Anaesthetist

D. G. JULIAN, M.D., F.R.C.P., Consultant Physician

\section{Introduction}

The operation of laparoscopy has recently achieved popularity in gynaecological surgery. Since 1966, in the Edinburgh Royal Infirmary, the number of such operations has been increasing annually, and currently more than 1,000 are performed per year, most being for sterilization.

Cardiac arrhythmias are a fairly common occurrence during the procedure (Scott, 1970), presumably because it is impossible to prevent a degree of hypercarbia (especially if the respiration is spontaneous) when carbon dioxide is used to inflate the abdomen. Thus if halothane is being administered arrhythmias are to be expected in a proportion of cases. It might be possible, therefore, to limit the rise in $\mathrm{PaCO}_{2}$ during insufflation, and thereby reduce the incidence of arrhythmias, if nitrous oxide were used in the place of carbon dioxide as the insufflating gas.

The present study was undertaken for the following purposes: (a) to assess the incidence of cardiac arrhythmias during laparoscopy and to determine the types of arrhythmia occurring, and 